Portland State University

PDXScholar

9-9-2019

\title{
Literature Review of the Effectiveness of Intercultural Competence in the MEPI Program
}

Haley L. Wells

Portland State University

Follow this and additional works at: https://pdxscholar.library.pdx.edu/honorstheses

Let us know how access to this document benefits you.

\section{Recommended Citation}

Wells, Haley L., "Literature Review of the Effectiveness of Intercultural Competence in the MEPI Program" (2019). University Honors Theses. Paper 793.

https://doi.org/10.15760/honors.811

This Thesis is brought to you for free and open access. It has been accepted for inclusion in University Honors Theses by an authorized administrator of PDXScholar. Please contact us if we can make this document more accessible: pdxscholar@pdx.edu. 
Literature Review of the Effectiveness of Intercultural Competence in the MEPI Program By

\section{Haley Wells}

An undergraduate honors thesis submitted in partial fulfillment of the

requirements for the degree of

\section{Bachelor of Arts}

in

University Honors

and

World Languages \& Literatures: Arabic and International \& Global Studies: Global Studies

Thesis Advisor

Kimberley Brown Ph.D.

Portland State University 


\section{Table of Contents}

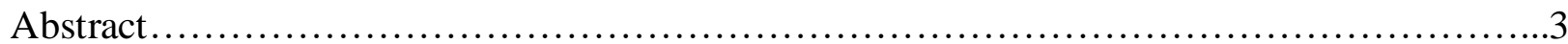

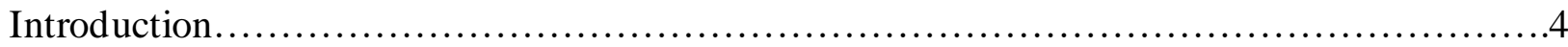

Intercultural Competence..................................................4

The MEPI Program...........................................................

Importance of Intercultural Competence......................................6

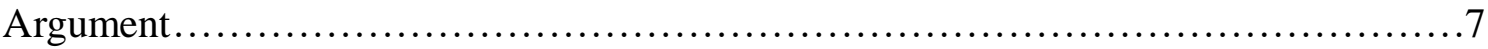

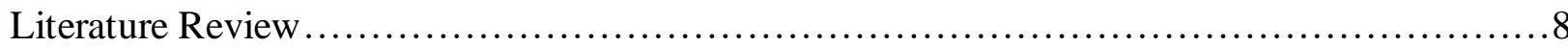

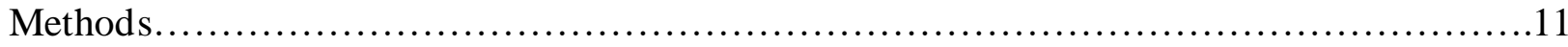

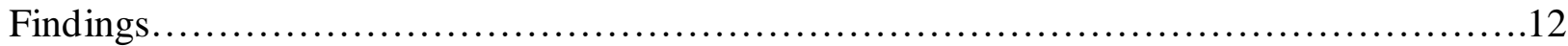

Areas of Rubric found in MEPI Documents.....................................12

Commonalities and Differences between MEPI Documents.......................14

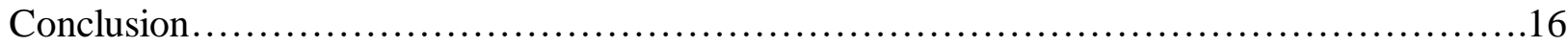

Overtness of Intercultural Competence Trainings in the MEPI Program................16

How could the Intercultural Competence in the MEPI Program be implemented........17

Further Research...........................................................19

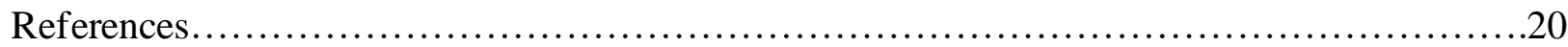

Appendix

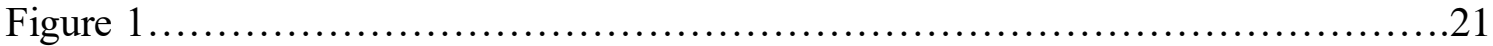

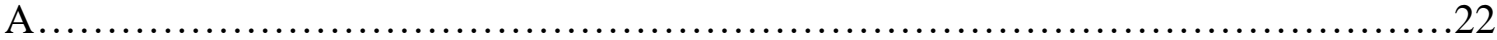

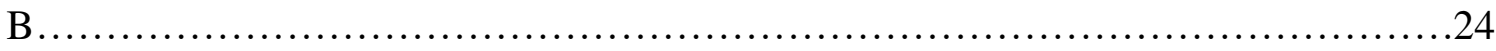

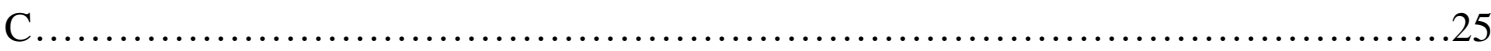


INTERCULTURAL COMPETENCE AND THE MEPI PROGRAM

\begin{abstract}
This research examines the Middle Eastern Partnership Initiative Student Leaders Program (MEPI SLP) looking for components of intercultural competence in the classes and activities the students participate in during the four-week immersive program. During these four weeks Student Leaders from the Middle East and North Africa study conflict resolution, community leadership, and democratic institutions, build a community engagement project to implement in their home countries when they return, and participate in program and cultural activated chosen to use what they learn in the classroom. After analyzing documents obtained from MEPI administrators I used the Intercultural Competence and Knowled ge VALUE Rubric from the Association of American Colleges and Universities (AAC\&U) as a guide to find the six components of the rubric in the MEPI documents. From there I concluded that intercultural competence is not an overt teaching goal of the program, nor is it specifically reflected in planning documents, but there are places in the program where intercultural competence training could be applied.
\end{abstract}

Keywords: Middle Eastern Partnership Initiative, intercultural competence, study abroad programs, U.S. Department of State 


\section{INTERCULTURAL COMPETENCE AND THE MEPI PROGRAM}

\section{Introduction}

Intercultural Competence

As technology and people continue to advance in society, our world is constantly evolving and changing. The notion of globalization can be found in almost all walks of life. There are businesses that operate world-wide; there are companies who employ people from all over the world. Study abroad programs are becoming increasingly commercialized for students, whether they are from the United States and go abroad or come to the United States from abroad. There are a range of different types of programs that are available, some through local governments, non-profit organizations, or through local universities. With all this global adventure there is an opportunity for education on the notion of intercultural competence. Intercultural competence is defined by Jackson, (2014) "The ability to communicate effectively and appropriately in intercultural situations based on one's intercultural knowledge, skills and attitudes" (p. 9). There are variations of this definition depending on what field is looking at intercultural competence and how it is being applied, but this is the most basic definition that fits within the humanities and social sciences. Intercultural competence is something that is made up of multiple factors that can be represented as a matrix, and there are many models that show different components of intercultural competence.

\section{The MEPI Program}

From 2002, the U.S. Department of State, Bureau of Near East Affairs, Office of Assistant Coordination, and Georgetown University have sponsored and administered the program Middle Eastern Partnership Initiative Student Leaders Program (MEPI SLP), MEPI for short. The goals of the program are to encourage civic engagement and participation in 


\section{INTERCULTURAL COMPETENCE AND THE MEPI PROGRAM}

communities, leadership abilities such as problem solving and conflict resolution, and soft or smart power skills such as communication, teamwork, interpersonal skills. (2018) The skills they learn from this program will allow them to successfully implement a community engagement project in their home countries upon returning from their five-week intensive immersion program. 60 student leaders are chosen from the Middle East North Africa and Southeast Asia (MENASA) region to come to the United States where they are divided between four partner universities across the country; currently the participating universities are Georgetown, University of Delaware, Montana State University and Portland State University. I was working as a Resident Program Assistant for the Portland Student Leaders, therefore most of the information I draw from pertains specifically to Portland and the general paperwork from the U.S. Department of State. Each week the Student Leaders took classes on different subjects: the first week was spent learning about conflict resolution tactics; the second week was community leadership which prepared them for the third week where the Student Leaders participated in a volunteer externship in the Portland area, and the last week was spent learning about comparative democratic governance. While learning these skills in class, the Student Leaders were also composing their community engagement projects to implement upon returning to their home countries. The skills offered in the classes were there to show them techniques to use when they returned home, and how to manage problems when implementing their projects, or how to be a successful leader to start their projects. Outside of class and program-required activities, the Student Leaders also were participating in cultural activities organized by the RPAs to further instill the concepts that were being taught each week in the classroom. Before the Student Leaders arrived in Portland the three RPAs met with the program coordinator to talk through some of the logistics of how the program should run and to discuss cultural activities related to 


\section{INTERCULTURAL COMPETENCE AND THE MEPI PROGRAM}

how they can improve their knowledge and understanding of the American culture in a leadership role. MEPI was my first real experience directly working with a group of students who were all from another culture, and even within them as a group they come from different cultures. Out of the 15 Student Leaders that were in Portland, they came from 7 separate countries from the Middle East and North Africa: Jordan, Lebanon, Israel, West Bank, Algeria, Tunisia and Morocco.

After MEPI was over, I took a class that was about intercultural communication and competence and after taking that class I was reflecting on my time during MEPI and several actions I took during MEPI, and I connected them to the things I read about in the material of the class of things that can promote positive cross cultural encounters. After this reflection I used what I learned from the class and MEPI and applied it to my own study abroad experience when I spent the spring term of my senior year as an undergraduate in Amman, Jordan. Learning about the customs and goals of welcoming a new culture into yours made my perspective of entering a new culture very interesting, looking at the different things that were done to make this group of students feel welcome in a very unfamiliar country. These experiences led me to take a deeper look at intercultural competence and how it is and can be better utilized in this world.

Importance of Intercultural Competence

Intercultural competence is important to study abroad programs, global leadership, internationalization and more because the basis of all these topics is the mixing of different cultures. This can be in a social setting, business setting, or an educational setting, U.S. students travelling abroad for a semester, international students travelling to the United States, global business leaders meeting, or organizations who work around the globe. All these individuals are in search of where the best place is to study their particular specialization, or have their business 


\section{INTERCULTURAL COMPETENCE AND THE MEPI PROGRAM}

be the most successful etc. But before any of these things can be accomplished there needs to be some level of understanding of intercultural competence. One problem that could arise in trying to understand intercultural competence is the vast amount of terms that could all be under the same umbrella as intercultural competence. Hammer, (2015) states:

"Intercultural competence has been identified with a bewildering set of terms, including intercultural sensitivity, cross-cultural effectiveness, intercultural skills, cross-cultural adaptation, global competence, multicultural competence, cross-cultural relations, cultural proficiency, intercultural agility, and even the misnomer cultural intelligence.” (p. 483)

Because of the breadth of disciplines operationalizing intercultural competence, it can sometimes be difficult to narrow search terms to measure the presence or absence of intercultural components in training and leadership programs. The formal integration of international competence training into business and study abroad programs can shape outcomes for participants.

Research from the University of Minnesota, Mankato concluded that "There are at least four primary areas in which international education is considered to have an impact: professional role, international perspectives, personal development and intellectual development" (Sandall, 2007, p. 3). This applies not only to students but to teachers as well, those who have students from a different community, or families who host international students. Because intercultural competence can be taught and used by everyone that is why it is important to study it, learn how to effectively teach and implement it into internationally based programs, and know how and when to use those skills as a parent, teacher, student, or friend. 


\section{INTERCULTURAL COMPETENCE AND THE MEPI PROGRAM}

\section{Argument}

For this research I am using the Intercultural Knowledge and Competence VALUE Rubric by the Association of American Colleges and Universities (AAC\&U, 2009). I am going to be looking at the components that make up intercultural competence using the VALUE rubric. (See Appendix A for full rubric). This rubric breaks down the 6 key components to reaching intercultural competence: Cultural self-awareness, Knowled ge of cultural world view frameworks. Empathy, Verbal and non-verbal communication, Curiosity, and Openness. Each of these components are scaled from 1-4 with 1 being "Benchmark" level, 2 and 3 "Milestones" and 4 "Capstone". This rubric is used as an assessment tool to identify the degree to which students demonstrate competence and knowledge through written and oral work. Using this rubric, I will analyze documents obtained through the MEPI program and from administrative staff of the program to find concepts that are in the rubric in the MEPI documents. I have what is labeled the Global Welcome Packet that is distributed to the Student Leaders from the U.S. Department of State and the Student Leaders Program Curriculum Packet that is specific for the Portland State Student Leaders that explains the classes and activities the Student Leaders will be participating in with a comprehensive calendar of the entire schedule. When describing these connections, I will be using my own perspective from participating as an RPA in the program to demonstrate the overtness of the areas of intercultural competence within the program and the events that the program participated in. I will be arguing that the areas of the rubric can be found in the documents and goals of the program, but they are underlying factors, as this program is labeled as an educational program with a community engagement project, not one specifically designed to foster intercultural competence for future global leaders.

\section{Literature review}




\section{INTERCULTURAL COMPETENCE AND THE MEPI PROGRAM}

\section{Commonalities in the Discourse Community}

One overarching theme that I found doing my research was the challenge that intercultural competence is hard to define, measure and universally structure (Deard orff, 2009). There are multiple components that make up intercultural competence that are difficult to measure, such as one's level of empathy and curiosity for another culture, whereas something like self-awareness and verbal and non-verbal communication can be quantified similarly to tests in the field of psychology. "This lack of specificity in defining intercultural competence is due presumably to the difficulty of identifying the specific components of this complex concept" (Deard orff, 2006 p. 241). It is difficult to find one definition that can encompass the many factors that contribute to intercultural competence, in addition to agreeing on the factors that are to contribute to the definition. If there is a consensus of a definition, it is impossible to be applied in every context. One definition might be clearer in one region than another, and there are possible cultural factors that can hinder the accuracy of a definition. Additionally, if one desires to define intercultural competence in a way to apply it to an international team of members who are working remotely from their countries using technology as a source of communication, other organizations of the concept may be in order. There is a bigger picture of internationalization that intercultural competence seems to be tangled with. Zeleza, (2012) says:

Perhaps the most succinct and nuanced definition is that provided by Jane Knight who sees internationalization as the "process of integrating an international, intercultural or global dimension into the purpose, functions or delivery of postsecondary education" (p. 2). 


\section{INTERCULTURAL COMPETENCE AND THE MEPI PROGRAM}

The clear difference here is that internationalization is an attempt at integration of cultures where intercultural competence is the ability to communicate and interact respectfully with another culture without trying to change them.

Another theme I noticed in the literature was how the topics of intercultural communication, global leadership, and intercultural competence were all closely knit together, and it was difficult but necessary for me to distinguish the difference. Although verbal and nonverbal communication are factors that contribute to intercultural competence, intercultural communication is focused more on the level of fluency with the native language, understanding the cultural aspects of a language that can make it seem like you are integrating more into their lifestyle and culture (Jackson, 2014). Using media as communication can also impact the way someone can measure intercultural competence. Even within the same language and culture there are messages sent over message boards or texting that can be misunderstood due to interpretation. Video chatting where you can see facial cues and expressions are more helpful in this particular cross-cultural encounter.

Savicki, (2008) suggests that most educators do not have specific training to be able to interact, talk to, and deal with international students, or be an international educator: "The failure of some study abroad students to develop an intercultural or multicultural perspective does not indicate they are dense or defective. Rather it may indicate a lack of adequate teaching and modeling by study abroad program personnel" (2008 p. 344-345). Having adequate knowled ge and understanding of how to teach students from another culture, or how to approach professors of the host culture, what is culturally acceptable if you are living in a home stay with a traditional family, knowing even a few of the customs of the host culture can be a major key to understanding intercultural competence. But a similar problem to how to define intercultural 


\section{INTERCULTURAL COMPETENCE AND THE MEPI PROGRAM}

competence in a specific field, having a comprehensive orientation for students is also a difficult task for study abroad offices at universities. Every country has its own culture and attempting to bunch every study abroad experience into one oversimplification is negligible. The first impression is a building block of the student's ability of gaining intercultural competence, staying open to learning about the culture, being curious and confident enough to ask questions which are aspects of intercultural competence that the VALUE rubric labels as important components. The last reoccurring theme that was present in the literature was the recommendation to implement post program evaluations to solidify the teachings from the program and maximize the lasting effects of the experience while abroad.

\section{Methods}

\section{AAC\&U VALUE Rubric}

The AAC\&U VALUE rubric that I compared the MEPI documents to is used by colleges and universities in the United States to document learning outcomes and give feedback to faculty and staff of programs that are teaching techniques of intercultural competence (AAC\&U, 2009). The rubric is made up of six components and measured by levels of success that are labeled with numbers one through four, one "benchmark", two and three "milestones", and four "capstone". Each level of the rubric shows more demonstrations of understanding of the six main components that make up the rubric. The six components are: 1. Cultural self-awareness 2 . Knowledge of cultural world view frameworks 3. Empathy 4. Verbal and non-verbal communication 5. Curiosity and 6. Openness. Labeled with numbers one through six, I systematically combed through the documents obtained from MEPI and labeled each aspect of the program I saw that fit one or multiple components from the rubric and wrote the corresponding number next to it. Once I finished with that, I counted how many times each 


\section{INTERCULTURAL COMPETENCE AND THE MEPI PROGRAM}

component was flagged and put those data points into a table (See Appendix B). I chose the numbers based on the definition of what each component meant; I did not assign a level of success because I feel that is an answer that would differ from student to student in the program and I am strictly looking at the descriptions of classes and activities and then using my perspective of attending the events as an RPA and watching them participate to see if the goals of the activity were being met.

I chose the AAC\&U VALUE Rubric because I was familiar with it from a class I took at PSU and I felt that it was comprehensive for the task I was attempting with the MEPI documents. I found the rubric easy to read and understand for how I was applying it to my research. There are several other models of intercultural competence out there to use, but for the focused purposes of looking at the MEPI Program, this VALUE Rubric was simple and easy to use and code with the documents.

\section{Findings}

Areas of Rubric found in MEPI Documents

First, I went through the MEPI documents listed in Figure 1. I looked at the Global Welcome Packet that was written for all 60 participating students in the program. It was written by the U.S. Department of State and Georgetown University, the two grantees of the program, and it was distributed to the students and program administrators. Most of the information in the welcome packet is logistical information that the students needed to prepare for their trip here, information about travelling and arriving to the United States, some basic social norms and customs of the U.S., program overviews and expectations, dorm life and staying healthy when surrounded by the same people all day for four weeks straight. Most of the logistical information 


\section{INTERCULTURAL COMPETENCE AND THE MEPI PROGRAM}

does not apply to intercultural competence and the only section I found any comments of intercultural competence practices was in the program expectations: "The cornerstone of a successful program and exchange experience is respect. Respect means treating people with kindness and understanding" (2018, p. 7). This fell under the third component, empathy. The second comment found stated "As Student Leaders, we expect you to respect everyone involved with the program - including students, staff, faculty and guest speakers - regardless of race, religion, nationality, gender, age, or any other attribute" (2018, p. 7). This I labeled as falling under categories 1- cultural self-awareness, 2- knowledge of cultural world view frameworks, 3empathy, and 6- openness. I chose these four components because as the RPA I saw the Student Leaders interacting with each other and the RPA team with respect even after weeks of spending our entire time together, which I know can be difficult for people depending on their personality types and how easily they are overwhelmed. This level of respect directly relates to the definition from the Rubric of empathy: "Ability to act in a supportive manner that recognizes the feelings of another cultural group" (AAC\&U, 2009). I witnessed the overflowing amount of respect that they showed for program staff, the faculty teaching their classes and all the other program affiliates we encountered in our activities and I could see them understanding that every activity and person they are conversing with was an opportunity to learn something new, or learn about other people's perspectives. One particular time, there was an event where PSU students were volunteering with the MEPI Student Leaders at a local Portland farm and there was a moment where two Student Leaders were speaking with a gentleman who was Native American and they were so involved in the conversation, if the group wouldn't of had to move to another station they could have spent the entire day asking questions and comparing experiences with this gentleman. What stood out to me was the knowledge the Student Leaders had about Native 


\section{INTERCULTURAL COMPETENCE AND THE MEPI PROGRAM}

Americans helped them formulate the questions they were asking and how respectful they were of the boundaries the gentleman had of his knowled ge or how comfortable he was talking about his heritage. As for the rest of the welcome packet I did not find any specific comments that I could attribute to intercultural competence.

The second document I looked at was the Student Leaders Program Curriculum Peacebuilding, Community Leadership, Democracy, and Project Management for Portland State University (See Appendix C for complete coded document). This was a document explaining in much more detail, a mini syllabus for each, the three classes the students would attend, conflict resolution, community leadership and democratic institutions. Then there were descriptions of what is expected for the community engagement project they were building, the goals they learned from the Portland Art Museum, the three-day community service externship, and the community-based learning events. After that there is a short section of student responsibilities with a comprehensive program calendar at the end. Some of the comments I flagged could be considered overlap because the first comment flagged was in the initial description of the class or activity, but in the calendar, I flagged it again where it gave more specific details of the class or activity. I did not record the number of repeated flags, where initially it was flagged in the description then again in the calendar, because both types of comments fell under multiple categories in the rubric.

In Appendix B, there is a table citing all the comments that I flagged as possible components of intercultural competence from each of the documents. Also, Appendix C shows examples of where I coded the descriptions and the details in the calendar.

Commonalities and differences found in MEPI documents 


\section{INTERCULTURAL COMPETENCE AND THE MEPI PROGRAM}

It was surprising that the Global Welcome Packet had only two comments that I flagged that were overt descriptions of components of intercultural competence. Most of the packet was descriptions of cultural norms, types of people the Student Leaders might run into, and the diversity of this country and its regions. But the small section that I did flag comments from was what the U.S. Department of State and Georgetown agreed on the expectations of the program for the students. Another document, the Student Leaders Program Curriculum shadows the expectations section of the welcome packet describing in detail how the three classes, the community externship, the community engagement project and cultural activities would reach their program goals.

When coding the Curriculum packet, I found an even number of flagged comments, 20 recordings each, for the components of knowledge of cultural worldview frameworks and curiosity. I think these two components could have a lot of overlap because if there is something that students do not understand the solution would be to ask questions. I saw that Student Leaders had no hesitation with asking questions and the answers usually fostered more questions. There were also two instances where only certain times in the activity that I thought could be attributed to components of intercultural competence. For example, MEPI partnered with the Portland Art Museum where we had three different activities over the course of the program with them. The partnership was based on the galleries they had set up at the time that were focused on how art can portray and support social change. The coordinator from the museum was supposed to tie the art work to what the students were learning in class, which is why I labeled it as promoting components 5 and 6, curiosity and openness, from the rubric, but witnessing the interactions of the students in the museum I would argue that they displayed more of components 3 and 4, empathy and verbal and non-verbal communication. Some of the art work depicted 


\section{INTERCULTURAL COMPETENCE AND THE MEPI PROGRAM}

Native Americans and the Student Leaders were fascinated by that community of people and their history and we stayed in this small section of the museum for almost an hour and a half before the facilitator finally had to stop the questions and move on to the next section, as they were fascinated by the art work showing scenes of battle, traditional clothing, and tools that they used. But to say that this was an unmet goal of the program would be not completely accurate because the Student Leaders were very curious about the culture, but they never tied it back to social change, or leadership or conflict resolution. And the goal was to tie the art and social change to their learnings from the two classes and there was a slight disconnect with pairing those two.

\section{Conclusion}

Overtness of Intercultural Competence Trainings in the MEPI Program

In all the paperwork that I have from the MEPI Program, and from what I was told by faculty and staff of the program, MEPI is an educational program whose purpose is to foster relationships between MENA region Student Leaders and the United States where they were taught about conflict resolution, community leadership, and democratic institutions so they can successfully implement their community engagement projects in their home countries and promote civic engagement from their peers. But if you look closer at the teachings and activities you see many places where components of intercultural competence trainings are found in the program when you have the correct guide to help you find them. The components that I flagged were based more from my experiences as an RPA then the written descriptions and goals from the paperwork and more from seeing the Student Leaders experience the classes and activities and then reviewing their experiences and picking out the components from the rubric that I saw come to fruition. This leads me to the conclusion that intercultural competence is not an overt 


\section{INTERCULTURAL COMPETENCE AND THE MEPI PROGRAM}

training that is built in to the MEPI program. If in the future the program wanted to implement more overt teachings of intercultural competence, they would need to build off the underlying factors of the program and make their presence more known and understood by the students.

A personal goal of mine was that I wanted to show them how I lived and what traditions I had with my family. I wanted them to feel welcome when they arrived because I have previous experience moving to a new place and it can be overwhelming. I decorated their doors with their names and images of things that they studied or activities we were doing during their stay and each week I added a new picture. I also worked with my mom and grandmother and made each of them a tie blanket to use and have as a lasting memory to bring home. A tradition in my family that is very valuable to us is eating together, so I volunteered to work with another RPA to make them some type of breakfast every morning so they are ready to go for the day, they are properly taken care of so they can focus on class instead of being hungry. I think that eating and starting the day together really brought everyone closer and gave them all a spot to hang out and get to know one another and even us as RPAs. I think the extra effort I put in for those 15 students made a lasting impression on them and when I took a semester to study abroad in Jordan we had a mini MEPI reunion and it was so great to hear them tell stories of their time in Portland and how much they all appreciated the things that not only I did but us as an RPA team did.

How could the Intercultural Competence in the MEPI Program be implemented

The first step into implementing more intercultural competence training into the MEPI program would be to look at the Global Welcome packet. The Global Welcome packet document leaves a huge gap for improvement where they could have had a pre-departure Q\&A with the students to go over or clarify any of the concerns or confusions that came from reading the welcome packet. There are many technological options to do this, there are programs that global 


\section{INTERCULTURAL COMPETENCE AND THE MEPI PROGRAM}

companies use for meetings with international clients and employees for meetings, the students could all log on and ask questions or voice concerns to staff from Georgetown or the U.S. Department of State after they read through the welcome packet.

Another step the program could take is having a regimented schedule of meetings with RPAs and the Student Leaders to debrief from the activities and classes of the week and show how the things that they learned that week could be used to strengthen or develop intercultural competence. While I was an RPA we wanted to have weekly check in meetings to see how the students were feeling about classes and activities and we found that because we didn't schedule them that we never found a good time to gather all the students together to talk about the week. We had only one meeting before things got too overwhelming. Although I feel like us as the RPA team did not prepare well enough for the meeting to be successful in debriefing them for the week and I think that also contributed to the fact that we did not have another meeting.

Lastly, around six months after the program is completed there is an event called the Accelerator Workshop that is held somewhere in the MENA region where the students come back together to talk about their projects and the program. That is data that I could add to fully do a comprehensive overview of this program from start to finish. In previous years the Accelerator Workshop was open to all Student Leaders to attend but in 2018 the U.S.

Department of State changed the rules and the Student Leaders had to apply and show progress on their community engagement projects to be accepted to attend. It would be interesting to compare the data from the surveys from previous years where everyone attended the workshop to the current years where they must apply to see if the motivation to make a successful project is different. I am unaware of any repercussions of not implementing their community engagement 


\section{INTERCULTURAL COMPETENCE AND THE MEPI PROGRAM}

projects upon returning to their home countries, and if this is the case what is keeping them from treating the program as a vacation rather than an education.

\section{Further Research}

As stated above, if I were to continue this research, I would ask to have access to the information from the Accelerator Workshop and see if that could parallel as a post-program evaluation that would show more information on the success of teachings of intercultural competence. I would then try and build a template to use where other types of study abroad programs could be tested to find out if they have aspects of the program that could be enhanced by plugging in teachings of intercultural competence to further foster relationships between the host country and the students travelling there. A review of the literature showed that there needs to be more studies done on programs to find places where they can more overtly promote intercultural competence, and it is left as a missed opportunity for global leadership to emerge more predominately in our world. 


\section{INTERCULTURAL COMPETENCE AND THE MEPI PROGRAM}

\section{References}

Association of American Colleges and Universities (AAC\&U). (2009). Intercultural knowledge and competence VALUE rubric.

Deardorff, D. (2006). Identification and Assessment of Intercultural Competence as a Student Outcome of Internationalization. Journal of Studies in International Education, 241-266.

Deard orff, D. (2009). The SAGE Handbook of Intercultural Competence. Thousand Oaks: SAGE Publications Inc.

Global Welcome Packet (2018)

Hammer, M. R. (2015). The SAGE Handbook of Intercultural Competence Development. In D. Deardorff, Intercultural Competence Development (pp. 483-486). Thousand Oaks: SAGE Publications Inc.

Jackson, J. (2014). Introducing Language and Intercultural Communication. New York: Routledge.

Oleksiyenko, A. (2013). Organizational Legitimacy of International Research Collaborations: Crossing Boundaries int he Middle East. Minerva, 49-69.

Sand all, E. (2007). Impact of International Education Experiences on the Undergraduate Students. ResearchGate, 1-17.

Savicki, V. (2008). Developing Intercultural Competence and Trasnformation. Sterling: Stylus.

Schnabel, D., Kelava, A., \& van de Vijver, F. J. (2016). The Effects of Using Collaborative Assessment with Students Going Abroad: Intercultural Competence Development, Self Understanding, Self-Confidence, and Stages of Change. Journal of College Student Development, 79-94.

Student Leaders Program and Curriculum (2018)

Tubbs, S., \& Schulz, E. (2006). Exploring a Taxonomy of Global Leadership Competencies and Meta-competencies. The Journal of American Academy of Business, Cambridge, 29-34.

Zeleza, P. T. (2012). Internationalization in Higher Education: Opportunities and Challenges for the Knowledge Project in the Global South. Maputo: Southern African Regional Universities Association. 
INTERCULTURAL COMPETENCE AND THE MEPI PROGRAM

Figure 1

\begin{tabular}{|c|c|c|c|}
\hline Documents & $\begin{array}{c}\text { Distributed to MEPI } \\
\text { Staff }\end{array}$ & $\begin{array}{c}\text { Distributed to MEPI } \\
\text { Student Leaders }\end{array}$ & $\begin{array}{c}\text { Information about } \\
\text { U.S. Dept. of State or } \\
\text { Portland State }\end{array}$ \\
\hline $\begin{array}{c}\text { Global Welcome } \\
\text { Packet }\end{array}$ & Yes & Yes & U.S. Dept. of State \\
\hline $\begin{array}{c}\text { Student Leaders } \\
\text { Program Curriculum } \\
\text { and Calendar }\end{array}$ & Yes & Yes & Portland State \\
\hline
\end{tabular}




\section{Appendix A}

\section{Intercultural Knowledge and Competence VALUE Rubric}

\section{INTERCULTURAL KNOWLEDGE AND COMPETENCE VALUE RUBRIC for more information, please contact value@aacu.org}

The VALUE rubrics were developed by teams of faculty experts representing colleges and universities across the United States through a process that examined many existing campus rubrics and related documents for each learning outcome and incorporated additional feedback from faculty. The rubrics articulate fundamental criteria for each learning outcome, with performance descriptors demonstrating progressively more sophisticated levels of attainment. The rubrics are intended for institutional-level use in evaluating and discussing student learning, not for grading. The core expectations articulated in all 15 of the VALUE rubrics can and should be translate into the language of individual campuses, disciplines, and even courses. The utility of the VALUE rubrics is to position learning at all undergraduate levels within a basic framework of expectations such that evidence of learning can by shared nationally through a common dialog and understanding of student success.

\section{Definition}

Intercultural Knowledge and Competence is "a set of cognitive, affective, and behavioral skills and characteristics that support effective and appropriate interaction in a variety of cultural contexts." (Bennett, J. M. 2008. Transformative training: Designing programs for culture learning. In Contemporary leadership and intercultural competence: Understanding and utilizing cultural diversity to build successful organizations, ed. M. A. Moodian, 95-110. Thousand Oaks, CA: Sage.)

$$
\text { Framing Language }
$$

The call to integrate intercultural knowledge and competence into the heart of education is an imperative born of seeing ourselves as members of a world community, knowing that we share the future with others. Beyond mere exposure to culturally different o thers, the campus community requires the capacity to: meaningfully engage those others, place social justice in historical and political context, and put culture at the core of transformative learning. The intercultural knowledge and competence rubric suggests a sys tematic way to measure our capacity to identify our own cultural patterns, compare and contrast them with others, and adapt empathically and flexibly to unfamiliar ways of being. The levels of this rubric are informed in part by M. Bennett's Developmental Model of Intercultural Sensitivity (Bennett, M.J. 1993. Towards ethnorelativism: A developmental model of intercultural sensitivity. In Education for the intercultural experience, ed. R. M. Paige, 22-71. Yarmouth, ME: Intercultural Press). In addition, the criteriain this rubric are informed in part by D.K. Deardorff's intercultural framework which is the first research-based consensus model of intercultural competence (Deardorff, D.K. 2006. The identification and assessment of intercultural competence as a student outcome of internationalization. Journal of Studies in International Education 10(3): 241-266). It is also important to understand that intercultural knowledge and competence is more complex than what is reflected in this rubric. This rubric identifies six of the key components of intercultural knowledge and competence, but there are other components as identified in the Deardorff model and in other research.

\section{Glossary}

The definitions that follow were developed to clarify terms and concepts used in this rubric only.

- Culture: All knowledge and values shared by a group.

- Cultural rules and biases: Boundaries within which an individual operates in order to feel a sense of belonging to a society or group, based on the values shared by that society or group.

- Empathy: "Empathy is the imaginary participation in anotherperson's experience, including emotional and intellectual dimensions, by imagining his or her perspective (not by assuming the person's position)". Bennett, J. 1998. Transition shock: Putting culture shock in perspective. In Basic concepts of intercultural communication, ed. M. Bennett, 215-224. Yarmouth, ME: Intercultural Press.

- Intercultural experience: The experience of an interaction with an individual or groups of people whose culture is different from your own. Intercultural/cultural differences: The differences in rules, behaviors, communication and biases, based on cultural values that are different from one's own culture.

- Suspends judgment in valuing their interactions with culturally different others: Postpones assessment or evaluation (positive or negative) of interactions with people culturally different from one self. Disconnecting from the process of automatic judgment and taking time to reflect on possibly multiple meanings.

- Worldview: Worldview is the cognitive and affective lens through which people construe their experiences and make sense of the world around them.

INTERCULTURAL KNOWLEDGE AND COMPETENCE VALUE RUBRIC for more information, please contact value@aacu.org

Definition

Intercultural Knowledge and Competence is "a set of cognitive, affective, and behavioral skills and characteristics that support effective and appropriate interaction in a variety of cultural contexts." (Bennett, J. M. 2008. Transformative training: Designing programs for culture learning. 


\section{INTERCULTURAL COMPETENCE AND THE MEPI PROGRAM}

In Contemporary leadership and intercultural competence: Understanding and utilizing cultural diversity to build success ful organizations, ed. M. A. Moodian, 95-110. Thousand Oaks, CA: Sage.)

Evaluators are encouraged to assign a zero to any work sample or collection of work that does not meet benchmark (cell one) level performance.

\begin{tabular}{|c|c|c|c|c|}
\hline & \multirow{2}{*}{$\begin{array}{c}\text { Capstone } \\
4\end{array}$} & \multirow{2}{*}{\multicolumn{2}{|c|}{ Milestones }} & \multirow{2}{*}{$\begin{array}{c}\text { Benchmark } \\
1\end{array}$} \\
\hline & & & & \\
\hline $\begin{array}{l}1 \text { Knowledge } \\
\text { Cultural self-awareness }\end{array}$ & $\begin{array}{l}\text { Articulates insights into own cultural rules } \\
\text { and biases (e.g. seeking complexity; aware } \\
\text { of how her/his experiences have shaped } \\
\text { these rules, and how to recognize and } \\
\text { respond to cultural biases, resulting in a } \\
\text { shift in self-description.) }\end{array}$ & $\begin{array}{l}\text { Recognizes new perspectives } \\
\text { about own cultural rules and } \\
\text { biases (e.g. not looking for } \\
\text { sameness; comfortable with the } \\
\text { complexities that new } \\
\text { perspectives offer.) }\end{array}$ & $\begin{array}{l}\text { Identifies own cultural rules } \\
\text { and biases (e.g. with a } \\
\text { strong preference for those } \\
\text { rules shared with own } \\
\text { cultural group and seeks the } \\
\text { same in others.) }\end{array}$ & $\begin{array}{l}\text { Shows minimal awareness of } \\
\text { own cultural rules and biases } \\
\text { (even those shared with own } \\
\text { cultural group(s)) (e.g. } \\
\text { uncomfortable with identifying } \\
\text { possible cultural differences with } \\
\text { others.) }\end{array}$ \\
\hline $\begin{array}{l}2 \text { Knowledge } \\
\text { Knowledge of cultural } \\
\text { worldview frameworks }\end{array}$ & $\begin{array}{l}\text { Demons trates sophisticated understanding } \\
\text { of the complexity of elements important to } \\
\text { members of another culture in relation to its } \\
\text { his tory, values, politics, communication } \\
\text { styles, economy, or beliefs \& practices. }\end{array}$ & $\begin{array}{l}\text { Demonstrates adequate } \\
\text { understanding of the complexity } \\
\text { of elements important to } \\
\text { members of another culture in } \\
\text { relation to its history, values, } \\
\text { politics, communication styles, } \\
\text { economy, or beliefs \& practices. }\end{array}$ & $\begin{array}{l}\text { Demonstrates partial } \\
\text { understanding of the } \\
\text { complexity of elements } \\
\text { important to members of } \\
\text { another culture in relation to } \\
\text { its history, values, politics, } \\
\text { communication styles, } \\
\text { economy, or beliefs \& } \\
\text { practices }\end{array}$ & $\begin{array}{l}\text { Demonstrates surface } \\
\text { understanding of the complexity } \\
\text { of elements important to } \\
\text { members of another culture in } \\
\text { relation to its history, values, } \\
\text { politics, communication styles, } \\
\text { economy, or beliefs \& practices. }\end{array}$ \\
\hline $\begin{array}{l}\text { Skills } \\
\text { Empathy }\end{array}$ & $\begin{array}{l}\text { Interprets intercultural experience from the } \\
\text { perspectives of own and more than one } \\
\text { worldview and demons trates ability to act in } \\
\text { a supportive manner that recognizes the } \\
\text { feelings of another cultural group }\end{array}$ & $\begin{array}{l}\text { Recognizes intellectual and } \\
\text { emotional dimensions of more } \\
\text { than one worldview and } \\
\text { sometimes uses more than one } \\
\text { worldview in interactions }\end{array}$ & $\begin{array}{l}\text { Identifies components of } \\
\text { other cultural pers pectives } \\
\text { but responds in all situations } \\
\text { with own worldview }\end{array}$ & $\begin{array}{l}\text { Views the experience of others } \\
\text { but does so through own cultural } \\
\text { worldview }\end{array}$ \\
\hline $\begin{array}{l}4 \text { Skills } \\
\text { Verbal and non-verbal } \\
\text { communication }\end{array}$ & $\begin{array}{l}\text { Articulates a complex understanding of } \\
\text { cultural differences in verbal and nonverbal } \\
\text { communication (e.g., demons trates } \\
\text { understanding of the degree to which people } \\
\text { use physical contact while communicating } \\
\text { in different cultures or use direct/indirect } \\
\text { and explicit/implicit meanings) and is able } \\
\text { to skillfully negotiate a shared } \\
\text { understanding based on those differences. }\end{array}$ & $\begin{array}{l}\text { Recognizes and participates in } \\
\text { cultural differences in verbal } \\
\text { and nonverbal communication } \\
\text { and begins to negotiate a shared } \\
\text { understanding based on those } \\
\text { differences. }\end{array}$ & $\begin{array}{l}\text { Identifies somecultural } \\
\text { differences in verbal and } \\
\text { nonverbal communication } \\
\text { and is aware that } \\
\text { misunderstandings can } \\
\text { occur based on those } \\
\text { differences but is still unable } \\
\text { to negotiate a shared } \\
\text { understanding. }\end{array}$ & $\begin{array}{l}\text { Has a minimal level of } \\
\text { understanding of cultural } \\
\text { differences in verbal and } \\
\text { nonverbal communication; is } \\
\text { unable to negotiate a shared } \\
\text { understanding. }\end{array}$ \\
\hline $\begin{array}{l}5 \text { Attitudes } \\
\text { Curiosity }\end{array}$ & $\begin{array}{l}\text { Asks complex questions about other } \\
\text { cultures, seeks out and articulates answers } \\
\text { to those questions which reflect multiple } \\
\text { cultural perspectives }\end{array}$ & $\begin{array}{l}\text { Asks deeper questions about } \\
\text { other cultures and seeks out } \\
\text { answers to those questions }\end{array}$ & $\begin{array}{l}\text { Asks simple or surface } \\
\text { questions about other } \\
\text { cultures }\end{array}$ & $\begin{array}{l}\text { States minimal interest in } \\
\text { learning more about other } \\
\text { cultures }\end{array}$ \\
\hline $\begin{array}{l}6 \text { Attitudes } \\
\text { Openness }\end{array}$ & $\begin{array}{l}\text { Initiates and develops interactions with } \\
\text { culturally different others. Suspends } \\
\text { judgment in valuing her/his interactions } \\
\text { with culturally different others. }\end{array}$ & $\begin{array}{l}\text { Begins to initiate and develop } \\
\text { interactions with culturally } \\
\text { different others. Begins to } \\
\text { suspend judgment in her/his } \\
\text { valuing interactions with } \\
\text { culturally different others. }\end{array}$ & $\begin{array}{l}\text { Expresses openness to most } \\
\text { if not all interactions with } \\
\text { culturally different others. } \\
\text { Has difficulty suspending } \\
\text { any judgment in her/his } \\
\text { interactions with culturally } \\
\text { different others and is aware } \\
\text { of own judgment and } \\
\text { expresses a willingness to } \\
\text { change. }\end{array}$ & $\begin{array}{l}\text { Receptive to interacting with } \\
\text { culturally different others. Has } \\
\text { difficulty suspending any } \\
\text { judgment in her/his interactions } \\
\text { with culturally different others } \\
\text { but is unaware of own judgment. }\end{array}$ \\
\hline
\end{tabular}


INTERCULTURAL COMPETENCE AND THE MEPI PROGRAM

\section{Appendix B}

\begin{tabular}{|c|c|c|c|c|c|c|c|}
\hline $\begin{array}{l}\text { How many } \\
\text { labels of } \\
\text { components in } \\
\text { documents }\end{array}$ & $\begin{array}{l}1 \text { Cultural Self } \\
\text { Awareness }\end{array}$ & $\begin{array}{l}2 \text { Knowledge of } \\
\text { cultural } \\
\text { worldview } \\
\text { frameworks }\end{array}$ & 3 Empathy & $\begin{array}{l}4 \text { Verbal and non- } \\
\text { verbal } \\
\text { communication }\end{array}$ & 5 curiosity & 6 openness & Total \\
\hline $\begin{array}{l}\text { Global Welcome } \\
\text { Packet }\end{array}$ & 1 & 1 & 2 & $\bar{x}$ & $\mathrm{x}$ & 1 & 5 \\
\hline PSU Curriculum & 9 & 20 & 9 & 7 & 20 & 10 & 75 \\
\hline
\end{tabular}


INTERCULTURAL COMPETENCE AND THE MEPI PROGRAM

\title{
Appendix C
}

\author{
Student Leaders Program 2018 Curriculum \\ PEACEBUILDING, COMMUNITY LEADERSHIP, DEMOCRACY, and PROJECT \\ MANAGEMENT \\ Portland State University
}

"No nation can remain both ignorant and free."

Thomas Jefferson

\section{Purpose:}

The purpose of this course is to help students gain skills in democracy literacy, community leadership, conflict resolution and peacemaking (2) - a bedrock basis for continuing intellectual, professional, and emotional growth (1) throughout the course of life. This course is designed to help students become more knowledgeable about democracy, civic leadership and resolving conflicts as well as to be better thinkers, better writers, more socially responsible citizens (1), and more aware of one's place in the long and complex history of the human experience.

The course is divided into three units, each led by a specialist:

1) Introduction to conflict resolution and peacebuilding

2) Introduction to leadership and community organizing

3) Introduction to democratic institutions in the USA and abroad

There will also be three ongoing components:

4) Introduction to project management and design - Mercy Corps

5) Art and civic engagement- Portland Art Museum

6) Community-based learning experiences and visits to local organizations

We will also pursue four overarching learning outcomes during these courses:

Inquiry and Critical Thinking: Students will learn various modes of problem solving using different disciplinary perspectives-problem posing, investigating, and conceptualizing - in order to become active, self-motivated, and empowered thinkers. 
Communication (4): Students will enhance their capacity to communicate in various wayswriting, graphics, quantitative literacy, and other visual and oral means - to collaborate effectively with others in group work, and to be competent in appropriate communication technologies.

The Variety of Human Experience (5): Students will enhance their appreciation for and understanding of the rich complexity of the human experience through the study of differences in ethnic and cultural perspectives, class, race, gender, sexual orientation and ability.

Ethical Issues and Social Responsibility $(\mathbf{5 , 6 )}$ : Students will expand their understanding of the impact and value of individuals and their choices on society, both intellectually and socially, through group projects and collaboration in learning communities.

\section{COURSE OUTLINE}

\section{UNIT ONE: CONFLICT RESOLUTION, DIALOGUE AND PEACEBUILDING STRATEGIES AND PRAXIS}

Department of Conflict Resolution

The first section of this course will explore the fundamental concepts and practices of dialogue, conflict resolution and peacemaking. Students will examine both micro and macro level processes that can be applied in the home contexts. Work will be both theoretical and experiential as Student Leaders practice tools of the trade and apply them to case scenarios. These processes will also be practiced in such a way as to inform group engagement throughout the MEPI process.

Key Concepts and Learning Objectives:

- Create an atmosphere of safety and trust to allow for deep exploration of inter-group issues

- Foster an understanding of different perspectives and experience, through the use of dialogic practice, information sharing and community building (2)

- Learn about different methods of conflict resolution and peacebuilding and their applicability to micro and macro level conflicts case studies

- Practice and experiment with different conflict resolution and peacebuilding skills and strategies

- Deepen understanding of identity as a core element to the causes of and intervention in conflict scenarios (1)

- Explore the relevance and applicability of these processes to the home contexts and regions *please see course calendar for readings and assignments

UNIT TWO: TRANSFORMATIVE COMMUNITY-B ASED LEADERSHIP - THEORY AND PRACTICE

\section{Department of Public Administration}

In the second section of this course Student Leaders explore the substantive area of leadership, with focus on both formal and informal community-level civic leadership. Students will 


\section{INTERCULTURAL COMPETENCE AND THE MEPI PROGRAM}

investigate key leadership theories, view and practice leadership skills, frame issues with a community/civic perspective, discuss and analyze leadership practices in the US and the Middle East/North Africa, and explore personal philosophies for community leadership that they wish to employ in their home context.

Key Concepts and Learning Objectives:

- Explore important theories of leadership and leadership development

- Understand and practice key civic leadership skills, including: a) written and oral communication; b) listening, synthesis and analysis (4)

- Understand ways to navigate institutional boundaries

- Frame issues facing a communities in terms of generating capacities for leadership $(2,3)$

- Learn about Portland's capacity for community-level leadership (6)

- Discuss leadership and change in the Arab world (2)

- Incorporate experiential learning for leadership development and academic success

- Engage in self-reflection and self-assessment as a means to articulate a personal philosophy of leadership for the common good (1)

*please see course calendar for readings and assignments

UNIT THREE: APPLYING LEADERSHIP: COMPARATIVE GOVERNANCE AND WORKING FOR CHANGE WITHIN POLITICAL SYSTEMS

\section{Department of Criminology}

The third section of this course will explore and compare the various governing forms and political structures between the MENA region and the United States. Students will take a close look at how free speech works within each country and how to facilitate change within the specific political systems. We will compare change in other countries and ascertain strategies that can be used to facilitate change in students' home countries. Participants will meet with leaders from the Muslim Education Trust and international human rights attorneys to learn from their experiences. By the end of the course, Student Leaders will develop a personal strategy for integrating their projects within the political structures of their home communities.

Key Concepts and Learning Objectives:

- Articulate a understanding of different governance models, (2)

- Explain the linkages between an organizing set of principles for political life and the implications for civil society

- Develop a personal strategy for thinking about their own responsibilities within the Student Leaders own community (1)

- Examine forms of governing from around the MENA region and the United States. (2)

*please see course calendar for readings and assignments

ONGOING COMPONENT: INTRODUCTION TO PROJECT MANAGEMENT AND DESIGN

\section{Project Management Instructor}

During the Mercy Corps segment of the program students will explore the theories and practices 


\section{INTERCULTURAL COMPETENCE AND THE MEPI PROGRAM}

of program management. In the workshops, participants will spend time evaluating, organizing and planning the strategies to be successful in implementing a civic engagement project. Students will learn about tools and approaches to project design in general, and then apply these tools to their identified area for civic engagement. During the final presentation, students will have the opportunity to gain critical feedback from development professionals on their project before they return to their home countries. Civic engagement project plans will include selfidentified partners in the home community, and training will help prepare students to engage partners at various stages of the project. Special consideration will be given to the unique opportunities and challenges present in the students' communities.

Key Concepts and Learning Objectives:

- Deepen understanding of theory of change

- Identify cross-national community issues and build confidence in the skills that already exist in the group $(2,5)$

- Understand the importance of the Do No Harm concept in planning a community engagement project

- Establish an understanding for the process to create effective and needed projects

- Gain confidence and knowled ge of the effectiveness of organizational tools

- Understand the framework and tools to build and deliver a presentation ONGOING COMPONENT: ART AND SOCIAL CHANGE

\section{Portland Art Museum}

To extend the PSU program's strong emphasis on engaging with Portland's community and culture (6), three sessions will be conducted with the Portland Art Museum (PAM). Students will gain an understanding of the ways in which symbols and ideas from multiple U.S. cultures are depicted through art and artifact. and the relationship between art and civic engagement and social change.. Sessions will be led by professional art education staff and local artists and activists, who will link the themes of civic engagement and community leadership to ideas of artistic expression/activism and the wider American socio-historical context (promotes 5,6, displays 3,4$)^{*}$. Student Leaders will have a chance to visit public art spaces and local art galleries. As public symbols, the arts can provide a medium for leadership and civic engagement. Through this lens, Student Leaders will explore civic leadership in the context of American history, culture, art, and society. Student Leaders will also receive a pass to the museum for the duration of the academic residency - this will allow them to visit the museum independently to more thoroughly interact with the exhibits on a personal level.

\section{ONGOING COMPONENT: CIVIC ENGAGEMENT}

Civic engagement activities in the U.S. allow students to deepen their understanding of community activism, practice their leadership skills, and reflect upon how they can effectively engage in civic life upon their return home. Civic engagement field work will include both direct service and strategic meetings with leaders to learn about advocacy, coalition building, and project management. There will be two main components to the Civic Engagement Field Work at Portland State University: 
Community-Based Learning Visits: Throughout the academic residency at PSU, Student Leaders will visit community-based organizations that will serve as models for civic engagement and social entrepreneurship. During the visits, students will participate in professional-level meetings with staff, and observe different leadership philosophies and problem-solving techniques employed by these organizations. These organizations represent a variety of different focus areas, including conflict resolution, community agriculture, community organizing, sustainable energy technology, immigrant/refugee integration, and criminal justice system reform. The visits will be relevant to the thematic content of each week of the program. Specific organizations to be visited are described in institute calendar below.

Three-Day Community Service Externship (3): MEPI Student Leaders will work in small groups for a three-day volunteer experience at a Portland-based community-serving organization. For three days, Student Leaders will learn about the organization, the community need and the population they serve, root causes of the issue and the organization's approach through direct volunteering activities. PSU student volunteers will participate in direct voluntary service alongside the MEPI Student Leaders, in order to provide context and student perspective on the community issues being explored.

\section{STUDENT RESPONSIBILITIES}

Student engagement in this course is critically important. Students are responsible for coming prepared to each class with questions, insights, alternative perspectives and personal "real world" case examples and illustrations of the material covered in the assigned reading and class discussion. Students are expected to be active listeners and provide constructive feedback to the work and commentary presented and discussed by peers, community partners, and the instructor. In other words, students are responsible for not just showing up to class but for being active participants; not just for being a consumer of the information covered in the reading and presented by others in the class, but for being co-producers of learning opportunities for self and others.

\section{Policies:}

\section{$\underline{\text { Attendance \& Tardiness }}$}

- Attend ance at all lectures, discussions and workshops is mandatory. You have a short time to participate in this program - you don't want to miss out on anything.

- Attendance will factor into the overall evaluation of your progress during the program

- Students are responsible for material covered and announcements made in their absence. If an absence is necessary, you should communicate with the instructor and peers to keep up on class activities.

- It is expected that students will arrive to class on time and stay for the duration.

Classroom Demeanor \& Courtesy

- Controversy with civility. Disagreement and diversity of opinions and ideas are encouraged. It is expected that in trying to understand differences discussion will always be respectful. Disruptive or offensive behavior has no place in an inclusive and 


\section{INTERCULTURAL COMPETENCE AND THE MEPI PROGRAM}

supportive learning environment. Students engaging in such behavior will be asked to leave.

- Come to class to be in class. Students are expected to come to class ready to focus. Please turn off cell phones or other devices before class and keep them off for the duration. If you use a computer for taking notes, please do not let it be a distraction for yourself or others.

- Active Engagement. Asking questions and participating in classroom discussions is welcomed and encouraged. Seminars and lectures are designed to be interactive and will include active learning and discussions of current events appropriate for each topic.

- Representation. In Community-based learning sessions, students formally represent the university, the instructor, the host community partners, and themselves both inside and outside the classroom. Professional behavior is expected at all times.

Academic Integrity

Students are expected to adhere to college policies. Please take special note of policies regard ing plagiarism and appropriate classroom behavior. The University's Code of Student Conduct may be found at http://www.pdx.edu/dos/codeofconducthttp://www.pdx.edu/dos/codeofconduct

http://www.pdx.edu/dos/codeofconduct

\section{Additional Instructor Expectations:}

- Care and attention to work - Students are expected to take care with assignments, including neatness, proofreading, and looking up uncertain words or grammar rules. If poor writing or sloppiness interferes with a fair reading of the work, assignments may be returned to students for revision.

\section{CLASS SCHEDULE AND ASSIGNMENTS}

All class sessions and assignments subject to change at instructor's' discretion.

\section{Dates}

Session-Activity 
INTERCULTURAL COMPETENCE AND THE MEPI PROGRAM

\begin{tabular}{|c|c|}
\hline July 2 & $\begin{array}{l}\text { Welcome Ceremony and Academic Orientation: Meet PSU SLP staff and faculty, } \\
\text { introductions, overview of PSU programming } \\
\text { Lunch and welcome reception to follow. } \\
\text { Academic Session: Conflict Resolution } \\
\text { Conflict Resolution and Peacebuilding- Introduction and Overview ( } 2.5 \text { hrs) } \\
\text { - Exploring Opportunities and Challenges in Peace and Conflict Resolution } \\
\text { - Activities in Listening, Questioning and Values } \\
\text { - Development of Dialogic Skills and Processes: } \\
\quad \text { - Questioning } \\
\quad \text { - Perspective Taking } \\
\quad \text { - Suspension } \\
\text { - Listening } \\
\text { Read: Little Book of Dialogue }\end{array}$ \\
\hline July 3 & $\begin{array}{l}\text { Academic Session: Conflict Resolution } \\
\text { Identity ( } 2.5 \text { hrs) } \\
\quad \text { - Identity Mapping } \\
\quad \text { - Identity based Conflict } \\
\text { - Continue with Case Studies } \\
\text { Read: Identity Issues } \\
\text { http://www.beyondintractability.org/bi-essay/identity-issues } \\
\text { Civic Engagement Fieldwork: Community-Based Learning } \\
\text { Visit to Resolutions Northwest ( } 3 \text { hrs) } \\
\text { Resolutions Northwest is a Portland-based organization that works to facilitate dialogue to } \\
\text { help people and groups connect across differences. In keeping with the theme of the week } \\
\text { (conflict resolution), Student Leaders will learn about resolving conflict and advancing } \\
\text { racial and social justice ( } 2,3,5)\end{array}$ \\
\hline July 4 & $\begin{array}{l}\text { Independence Day } \\
\text { Cultural Activity: Portland Pickles Baseball Game }(2,5,6) \\
\text { Student Leaders will experience America's pastime while engaging with PSU students and } \\
\text { community members. } \\
\text { Cultural Activity: Annual } 4^{\text {th }} \text { of July Waterfront Blues Festival } \\
\text { Student Leaders and RAs will attend the annual Waterfront Blues Festival, a major } \\
\text { Portland cultural event that showcases the work of both local and internationally-renowned } \\
\text { blues artists. }\end{array}$ \\
\hline
\end{tabular}




\begin{tabular}{|c|c|}
\hline July 5 & $\begin{array}{l}\text { Academic Session: Conflict Resolution } \\
\text { Interests, Positions, Needs and Values (2.5 hrs) } \\
\quad \text { - Stages of Ripeness } \\
\quad \text { - Practice with Case Studies } \\
\text { Read: Interests, Positions, Needs and Values } \\
\text { http://www.beyondintractability.org/bi-essay/interests } \\
\text { Training: International Development } 101 \text { at Mercy Corps Action Center }(3 \mathrm{hrs)}(2,5) \\
\text { Located in Mercy Corps' global headquarters in Portland, the Action Center promotes } \\
\text { global literacy through lectures, exhibits, seminars, and youth workshops. In this } \\
\text { workshop, participants explore what happens when disaster strikes, conflict erupts and } \\
\text { help is needed, and take a deeper look at the roadblocks, relationships and expectations } \\
\text { that development professionals experience. Mercy Corps field representatives will also } \\
\text { present about their work and discuss their on-the-ground experiences in international } \\
\text { development. }\end{array}$ \\
\hline July 6 & $\begin{array}{l}\text { Academic Session: Conflict Resolution } \\
\text { Direct and Structural Violence ( } 2.5 \mathrm{hrs}) \\
\quad-\quad \text { Peacekeeping, Peacemaking, Peacebuilding } \\
\text { - } \quad \text { Beginning to explore local case scenarios through the lens of Direct and Structural } \\
\text { Violence. } \\
\text { Forms of Conflict Resolution: } \\
\quad \text { - Negotiation } \\
\text { - Mediation } \\
\text { - } \quad \text { Facilitation } \\
\text { Read: Little Book of Conflict Transformation } \\
\text { Academic Session: Conflict Resolution } \\
\text { Visit to Portland Vietnam Memorial for closing and integration }(2 \mathrm{hrs)}(3,5) \\
\text { Dialogue, Case Studies, Conclusion of Conflict Resolution coursework } \\
\text { Depart for Home Hospitality Weekend (no overnight) }\end{array}$ \\
\hline July 7 & Home Hospitality Weekend (no overnight) \\
\hline July 8 & Home Hospitality Weekend (no overnight) (All, 1,2,3,4,5,6) \\
\hline
\end{tabular}


INTERCULTURAL COMPETENCE AND THE MEPI PROGRAM

\begin{tabular}{|c|c|}
\hline July 9 & $\begin{array}{l}\text { Academic Session: Community Leadership } \\
\text { Democratic Leadership - Theory and Practice ( } 2.5 \mathrm{hrs)} \\
\quad \text { - Key leadership traits, styles, challenges, responses, and results. } \\
\text { Read: } \\
\text { Required: R. N. Remen, Helping, Fixing, Serving; Northouse, Introduction to Leadership } \\
\text { (chapter 3) } \\
\text { Civic Engagement Fieldwork/Cultural Activity ( } 2 \text { hrs) (1,3) } \\
\text { MENA Region Entrepreneurship and Civic Life Panel } \\
\text { A panel of Arab-American professionals will discuss their professional development in the } \\
\text { U.S., their experiences of civic leadership in the U.S. and the MENA-region, and their } \\
\text { vision for the future of their home countries. } \\
\text { Academic Session: Gender and Politics in the MENA Region (1 Hr) } \\
\text { Dr. Benstead, Director of PSU's Middle East Studies Center, is an expert in women, } \\
\text { gender, and political participation in the MENA. She will present find ings from her recent } \\
\text { research on women's political electability. }\end{array}$ \\
\hline
\end{tabular}




\begin{tabular}{|c|c|}
\hline July 10 & $\begin{array}{l}\text { Community-Based Learning/Cultural Activity } \\
\text { Visit to Portland Art Museum ( } 2.5 \text { hrs) } \\
\text { - What is the role of the arts in society? What are the relationships between art and } \\
\text { social change? } \\
\text { - How is art deliberated within a particular political environment? How do people } \\
\text { come to consensus on what art means? Solicit case studies from MEPI home } \\
\text { countries. Eg. Saudis lifting cinema ban. } \\
\text { Workshop: Project Management Session \#1 } \\
\text { Introduction, Vision for Change, Issue Identification ( } 3 \text { hrs) } \\
\text { Activities: } \\
\text { - Vision for change } \\
\text { - Issue/national/personal issue brainstorming session } \\
\text { - Develop Leadership Quadrant and skill exchange } \\
\text { Learning Goals: } \\
\text { - To build an understanding of theory of change } \\
\text { - To identify common issues across nations and to build confidence in skills students } \\
\text { already have as leaders (2) }\end{array}$ \\
\hline July 11 & $\begin{array}{l}\text { Academic Session/Civic Engagement Fieldwork: Community Leadership ( } 3 \text { hrs) }(5,6) \\
\text { Visit to the Learning Gardens Laboratory } \\
\text { The Learning Garden Laboratory (LGL) is a } 12 \text {-acre garden education site located in } \\
\text { Southeast Portland that provides K-12, university students and community members } \\
\text { hand s-on and place-based education in sustainable gardening, leadership development and } \\
\text { the cultivation of a sustainable future. Students will learn about current projects at the } \\
\text { garden, and then have an opportunity to work side-by side with PSU students currently } \\
\text { involved in a service-learning "capstone" experience. } \\
\text { Read: } \\
12 \text { ways to Share Power } \\
\text { Civic Engagement Fieldwork: Public Event with PSU Middle East Studies Center }(2 \\
\text { hrs) (1) } \\
\text { Five MEPI SLs will be guest speakers in a public panel-style event about community } \\
\text { activism in the greater MENA region. The event will be held in collaboration with the PSU } \\
\text { Middle East Studies Center, and will be attended by faculty, students, staff, and }\end{array}$ \\
\hline
\end{tabular}


INTERCULTURAL COMPETENCE AND THE MEPI PROGRAM

\begin{tabular}{|c|c|}
\hline & community members \\
\hline July 12 & $\begin{array}{l}\text { Academic Session: Community Leadership (1 hr) } \\
\text { Asset-Based Community Change Practices } \\
\text { Read: } \\
\text { Required: If it's rats, It's Rats, and Stone Soup } \\
\text { Recommended: Green, When People Care Enough To Act, Chap 1-2 } \\
\text { Workshop: Communication and Social Change ( } 2 \text { hrs) } \\
\text { PSU professor Lee Shaker will speak with students about the power of social media as a } \\
\text { tool for civic engagement and activism and how to successfully leverage these important } \\
\text { online networks. } \\
\text { Workshop: Project Management Session \#2 } \\
\text { Identifying Issues for Civic Engagement ( } 3 \text { hrs) } \\
\text { Activities: } \\
\text { - Introduction to Do No Harm, keeping an open mind, thinking big } \\
\text { - Problem/Objective tree (Asset Based approach) } \\
\text { - SWOT/quadrant exercise } \\
\text { - Relationship Map } \\
\text { Learning Goals: } \\
\text { - Identify issue for civic engagement project } \\
\text { - Establish an understanding for the process and tools necessary to create "needed" } \\
\text { - Aivic engagement project } \\
\text { Recognize important potential pitfalls to avoid in creating civic engagement projects }\end{array}$ \\
\hline July 13 & $\begin{array}{l}\text { Academic Session: Community Leadership ( } 2.5 \text { hrs) } \\
\text { Bringing it all together } \\
\text { The "live" practice of facilitative leadership. } \\
\text { Read: } \\
\text { Required: Chase, MLK the Real Person } \\
\text { Recommended: Ronald Heifitz, Adaptive Leadership } \\
\text { Depart for weekend camping trip at Rock Creek Reservoir (optional) }\end{array}$ \\
\hline July 14 & \begin{tabular}{|l|} 
Weekend camping trip at Rock Creek Reservoir (optional) \\
\end{tabular} \\
\hline
\end{tabular}


INTERCULTURAL COMPETENCE AND THE MEPI PROGRAM

\begin{tabular}{|c|c|}
\hline July 15 & Weekend camping trip at Rock Creek Reservoir (optional) $(2,3,4,5,6)$ \\
\hline July 16 & $\begin{array}{l}\text { Pre-flection/ Introduction to Community Service Externship (1 hr) } \\
\text { Carol Gabrielli and Laura Lyons will facilitate a discussion framing the upcoming } \\
\text { experience and helping students set their expectations for volunteering with a local } \\
\text { organization. } \\
\text { Workshop: Project Management Session \#3 ( } 2.5 \mathrm{hrs)} \\
\text { Developing Log Frames for Civic Engagement Projects } \\
\text { Activities: } \\
\quad \text { - Log Frames } \\
\text { Learning Goals: } \\
\quad \text { - Build understanding for the information and analysis of issue and problem } \\
\quad \text { - Create confidence in the relationship between goals of project and activities } \\
\quad \text { Establish action plan for moving project forward in home country } \\
\text { Training (All, } \mathbf{1 , 2 , 3 , 4 , 5 , 6 ) : ~ H u m a n - C e n t e r e d ~ D e s i g n ~ a t ~ M e r c y ~ C o r p s ~ A c t i o n ~ C e n t e r ~ ( ~} 2 \\
\text { hrs) } \\
\text { Student Leaders will learn the basic concepts of human-centered design as an approach to } \\
\text { addressing community challenges and apply these concepts to a case study involving } \\
\text { displacement and migration. }\end{array}$ \\
\hline July & $\begin{array}{l}\text { Civic Engagement Fieldwork: Community Service Externship }(\mathbf{2 , 3 , 5 , 6 )} \\
\text { ( } 3 \text { hrs) } \\
\text { Student Leaders will engage in direct voluntary community service alongside current PSU } \\
\text { students. Through organizational observation and direct volunteering at local } \\
\text { organizations, Student Leaders will be exposed to models for addressing community issues } \\
\text { and the culture of volunteerism in the U.S. Student Leaders are guided to make } \\
\text { connections between these experiences and possible opportunities for voluntary civic } \\
\text { engagement upon return to their home communities. } \\
\text { Community-Based Learning/Cultural Activity } \\
\text { Artist-led visit to Portland Art Museum (2 hrs) } \\
\text { SLs will explore issues of expression in artistic form, and the role of the media in civic } \\
\text { activism. } \\
\quad \text { - What is the role of museums in society? } \\
\text { - What is the place of cultural heritage and preservation and cultural traditions in }\end{array}$ \\
\hline
\end{tabular}




\begin{tabular}{|c|c|}
\hline & $\begin{array}{l}\text { your countries? } \\
\text { - Possibly include Leila Haile (Ori Gallery) and Emily Squires (SMYRC) for art and } \\
\text { activism discussion and/or visit to Ori Gallery } \\
\text { Cultural Activity: Visit to Oregon Zoo }\end{array}$ \\
\hline July 18 & $\begin{array}{l}\text { Civic Engagement Fieldwork: Community Service Externship (continued) (3 hrs) } \\
\text { Workshop: Project Management Session \#4 (3 hrs) } \\
\text { Concrete Steps for Project Implementation } \\
\text { Activities: } \\
\text { - Work Breakdown Structure } \\
\text { - Network Diagram } \\
\text { - Establish Action Calendar } \\
\text { Learning Goals: } \\
\text { - Create understanding to tangibly enact project } \\
\text { - List tasks associated with project outcomes to further flesh out/detail action plan } \\
\text { - Create timeline for steps needed }\end{array}$ \\
\hline July 19 & $\begin{array}{l}\text { Civic Engagement Fieldwork: Community Service Externship (continued)(3 hrs) } \\
\text { Final day of volunteering with community organizations, closing, debrief, and integration. } \\
\text { PSU student co-volunteers to attend and participate in discussion. } \\
\text { Debrief of Community Engagement Externship ( } 1 \mathrm{hr})\end{array}$ \\
\hline July 20 & $\begin{array}{l}\text { Late Afternoon Departure for Seattle Learning Excursion: Positive Community } \\
\text { Change in the Pacific Northwest: Challenges and Opportunities }(2,5) \\
\text { Students will spend the weekend in Seattle, exploring models for community change to } \\
\text { compare with experiences and observations in Portland as well as in their home countries. } \\
\text { Activities will focus on entrepreneurship and regional cultural heritage. } \\
\text { - } 8: 20 \text { am Board Amtrak "Cascades" Train \#500 to Seattle } \\
\text { - } 11: 50 \text { am Arrive in Seattle } \\
\text { - } 12 \text { pm Lunch at Starbucks Reserve Restaurant at Starbucks World Headquarters } \\
\text { - } \quad 1: 30 \text { pm Q\&A with Starbucks' Global Social Impact Director, Majd Baniodeh at } \\
\quad \text { Starbucks World Headquarters } \\
\text { - } 3 \text { pm Check-in Seattle Sheraton } \\
\text { - } 7 \text { pm MEPI Community Dinner at Il Fornaio }\end{array}$ \\
\hline
\end{tabular}




\begin{tabular}{|c|c|}
\hline July 21 & $\begin{array}{l}\text { Seattle Learning Excursion: Positive Community Change in the Pacific Northwest: } \\
\text { Challenges and Opportunities } \\
\begin{array}{l}\text { - } 10 \text { am University of Washington Law School Tour and Q\&A with Associate Dean } \\
\text { of Experiential Education, Christine N. Cimini, JD }(2,5) \\
\text { - } 12 \text { pm Lunch at Seattle Center } \\
\text { - } 2 \text { pm Chihuly Glass Garden Museum Tour } \\
\text { - } 4 \text { pm Space Needle Tour } \\
\text { - } 6 \text { pm Independent dinner and self-directed Seattle exploration }\end{array}\end{array}$ \\
\hline July 22 & $\begin{array}{l}\text { Seattle Lening Excursion: Positive Community Change in the Pacific Northwest: } \\
\text { Challenges and Opportunities } \\
\begin{array}{l}\text { - } 11 \text { am MEPI Community Picnic at Gas Works Park sponsored by a local } \\
\text { - } 4 \text { pm Check-out of Seattle Sheraton } \\
\text { - } 6: 10 \text { pm Board Amtrak "Cascades" Train \#507 to Portland } \\
\text { - } 9: 40 \text { pm Arrive in Portland }\end{array}\end{array}$ \\
\hline July 23 & $\begin{array}{l}\text { Academic Session: Comparative Governance Models } \\
\text { Orientation/U.S. Constitution and the First Amendment and MENA governing models ( } 2.5 \\
\text { hrs) } \\
\quad \text { - Introduction into democratic thought and institutions. } \\
\text { - Course goals and objectives. } \\
\text { Read: } \\
\text { Jordan, T.L. (2012). The U.S. Constitution and Fascinating Facts About It. P. 45-50, Bill } \\
\text { of Rights. } \\
\text { Civic Engagement Field Work: Community-Based Learning Visit to US Attorney's } \\
\text { Office and Federal Courthouse ( } 2 \text { hrs) (2,5) } \\
\text { Meet with representatives from the US Attorney's office to discuss U.S. justice and legal } \\
\text { system, powers of the judicial branch and separation of powers in U.S. democracy. }\end{array}$ \\
\hline July 24 & $\begin{array}{l}\text { Community-Based Learning: Social Justice and Community-based Art Practices } \\
\text { A visit to the Portland Art Museum - }(2.5 \mathrm{hrs}) \\
\text { - } \quad \text { Introduction to art \& social change using zines and public performance \& } \\
\text { - } \quad \text { Art and printmaking } \\
\text { Workshop: Project Management Session \#5 } \\
\text { Building Confidence for Good Presentations; Taking Feedback ( } 3 \text { hrs }) \\
\text { Activities: } \\
\text { - Improve activities } \\
\text { - How to take feedback }\end{array}$ \\
\hline
\end{tabular}




\begin{tabular}{|c|c|}
\hline & $\begin{array}{l}\text { - } \text { Analysis of what makes a good presentation } \\
\text { - } \text { Preparation/practice of presentations } \\
\text { Learning Goals: } \\
\text { - } \quad \text { Build confidence for public speaking } \\
\text { - Understand basics of telling a story and presenting } \\
\text { - Preparing presentation for next session/ practice and memorization } \\
\text { Dinner with PSU President Dr. Rahmat Shoureshi }\end{array}$ \\
\hline July 25 & $\begin{array}{l}\text { Civic Engagement Fieldwork/Academic Session (5) } \\
\text { Visit to the Coffee Creek Correctional Facility, Wilsonville, Oregon (4 hrs) } \\
\text { The objective of this excursion is to learn about the U.S. Criminal justice system. Students } \\
\text { will tour the facility. A discussion on comparative governance in students' home countries } \\
\text { will follow. }\end{array}$ \\
\hline July 26 & $\begin{array}{l}\text { Academic Session: Comparative Governance Models (2,5) } \\
\text { Discuss how to work within the governing systems of Student Leaders home countries } \\
(2.5 \text { hrs) } \\
\text { Workshop: Project Management Session \#6 } \\
\text { Presentations, Feedback and Reflections ( } 3 \mathrm{hrs)} \\
\text { Activities: } \\
\text { - Presentations to Mercy Corps panel } \\
\text { - Feedback/Reflections } \\
\text { - Wrap up/Debrief } \\
\text { Learning Goals: } \\
\text { - Practice public speaking and professional presentation skills } \\
\text { - Recognize the importance of feedback } \\
\text { - Build confidence in project and the continuing need for input and work }\end{array}$ \\
\hline July 27 & $\begin{array}{l}\text { Civic Engagement Fieldwork/Academic Session } \\
\text { Visit to Oregon Innocence Project and guest lecture from Janis Puracal, founder of Oregon } \\
\text { Innocence Project ( } 2 \mathrm{hrs} \text { ) } \\
\text { - Explore a model for social change through progressive legal reform } \\
\text { - Discussion of MENA and US justice systems } \\
\text { - Engaged civic activism for social justice } \\
\text { Final Program Debrief } \\
\text { Staff, faculty, student leaders and RAs will come together for a final program debrief. } \\
\text { Students will share highlights and areas of opportunity for future years. } \\
\text { Program Closing Dinner }\end{array}$ \\
\hline
\end{tabular}


INTERCULTURAL COMPETENCE AND THE MEPI PROGRAM 